\title{
Polymorphisms in the Glucocorticoid Receptor Gene and Their Associations with Metabolic Parameters and Body Composition
}

\author{
Elisabeth F.C. van Rossum and Steven W.J. Lamberts \\ Department of Internal Medicine, Erasmus Medical Center, Rotterdam, The Netherlands
}

\begin{abstract}
Most actions of glucocorticoids (GCs) are mediated by the glucocorticoid receptor (GR). The interindividual response to GCs varies considerably, as demonstrated by a variable suppressive response to $0.25-\mathrm{mg}$ dexamethasone (DEX). Several polymorphisms in the gene coding for the GR have been described. It is unclear to what extent the observed response variability is due to GR polymorphisms or to other factors. However, at least three polymorphisms seem to be associated with altered GC sensitivity and changes in body composition and metabolic parameters. The N363S polymorphism has been associated with increased sensitivity to GCs, increased insulin response to DEX, a tendency towards lower bone mineral density, and increased body mass index (BMI). However, other reports found no associations with BMI. Another polymorphism, previously described as a $B c l$ r restriction fragment length polymorphism, recently was identified as a $\mathrm{C} \rightarrow \mathrm{G}$ nucleotide change. The G allele also was associated with increased sensitivity to GCs. In middle-aged subjects, the $\mathrm{G}$ allele of this $B c l$ I polymorphism was associated with increased abdominal obesity, while at older age, a lower BMI was found, accompanied by a tendency towards lower lean body mass. A third polymorphism consists of two linked, single-nucleotide mutations in codons 22 and 23, of which the second mutation results in an amino acid change from arginine (R) to lysine (K). In contrast to the other polymorphisms, this ER22/23EK polymorphism was associated with a relative resistance to GCs. In line with this, ER22/23EK carriers had lower total cholesterol and low-density lipoprotein cholesterol levels as well as lower fasting insulin concentrations and a better insulin sensitivity. C-reactive protein levels were lower in ER22/23EK carriers, as was found in a different population of elderly males. In accordance with this healthy metabolic profile, we found in this population a significantly better survival in ER22/23EK carriers after a 4-year follow-up. GCs also affect the brain. Although a certain level of cortisol is essential for proper brain functioning, excessive GC levels have been shown to negatively affect brain morphology and functions. At older age, we found that the risk of dementia and white matter lesions was lower in ER22/23EK carriers. GCs are also important in the regulation of body fat distribution. At young age, we observed sex-specific differences in body composition. Male ER22/23EK carriers were taller, had more muscle mass, and were stronger than noncarriers. In young females, ER22/23EK carriers had tendencies towards smaller waist and hip circumferences and lower body weight. Another polymorphism (TthIIII) was not associated with altered GC sensitivity. In conclusion, these polymorphisms in the GR gene may contribute considerably to the observed variability in GC sensitivity. As a result, they are associated with several differences in body composition and metabolic factors.
\end{abstract}




\section{Introduction}

Glucocorticoid (GC) secretion is regulated by the hypothalamus, which receives stimuli from the central nervous system (CNS) (Chrousos and Gold, 1992). This results in a diurnal profile of cortisol secretion, with high levels in the morning and low concentrations in the afternoon and evening, with a small peak after lunch. In obese individuals, cortisol secretion is elevated and its peripheral turnover rate is higher, which results in normal, or even lower, serum cortisol concentrations (Murphy, 1968; Streeten et al., 1969; Cheek et al., 1981). Dysregulation of the hypothalamo-pituitary-adrenal (HPA) axis was found to be more pronounced in central obesity than in peripheral or gluteofemoral obesity (Marin et al., 1992; Pasquali et al., 1993; Rosmond et al., 1998).

The regulation of cortisol metabolism in humans is not only centrally determined. Two key enzymes in cortisol metabolism have been identified that influence the effects of cortisol at the peripheral level: 11 beta-hydroxysteroid dehydrogenase (11 $\beta$-HSD) I and $11 \beta$-HSD II. The latter enzyme inactivates cortisol by conversion into cortisone, particularly in the kidney but also in other aldosterone-selective target tissues. The other enzyme, $11 \beta$-HSD I, is present predominantly in adipose tissue, liver, lung, vascular system, ovary, and CNS (Monder and White, 1993; Stewart and Krozowski, 1999). The function of $11 \beta$-HSD I is to convert cortisone into the active form, cortisol. Interestingly, in obese humans, this enzyme has been shown to have tissue-specific actions. $11 \beta$-HSD I activity is lower in the liver, while increased activity in vitro is observed in the subcutaneous adipose tissue of obese men. This results in higher local cortisol levels in adipose tissue, which is suggested to be an important factor in the mechanism leading to harmful metabolic consequences of obesity.

It is known that GC sensitivity, measured by a dexamethasone (DEX) suppression test, varies greatly between individuals (Huizenga et al., 1998b). However, within individuals, GC sensitivity is rather stable. This suggests that, in humans, a setpoint for DEX sensitivity with respect to the feedback action exists, which might be genetically determined. An important factor in the cascade of GC action, also at the pituitary level, is binding to the GC receptor (GR).

The GR belongs to the superfamily of nuclear receptors that are present in the cytoplasm and act as transcription factors to regulate gene expression. Following cortisol binding, a conformational change occurs that leads to dissociation of the receptor from a large complex of proteins, of which heat shock protein (HSP) 90 is the most important (Pratt and Toft, 1997; Toft, 1998). This activated, ligand-bound receptor translocates to the nucleus, where it can act in several ways (Schaaf and Cidlowski, 2003). The GR can initiate transcription through binding to GC-responsive elements of the target gene. The GR also can affect gene transcription through direct protein-protein interaction and can activate, as well as repress, target gene expression (Diamond et al., 1990; 
Yang-Yen et al., 1990; Yudt and Cidlowski, 2002). In mice in which a mutation was induced that impaired dimerization and DNA binding, these processes have been shown to be not critical for survival (Reichardt et al., 1998).

Previously, some rare mutations of the $G R$ gene were described that led to clinical signs and symptoms of generalized cortisol resistance (Lamberts et al., 1992). Due to these receptor defects, cortisol has impaired actions through the GR. As a consequence, the central negative feedback of GCs is diminished, GC production by the adrenal is elevated, and cortisol binds with high affinity to the mineralocorticoid receptor (MR). Symptomatology in patients with cortisol resistance is the consequence of a compensatory hyperactivity of the HPA axis, which results in overproduction of mineralocorticoids, which, in turn, leads to hypertension, hypokalemic alkalosis, fatigue, and in females - due to higher adrenal production of androgens - hyperandrogenism. In normal conditions, organs that have an important mineralocorticoid function are protected from high cortisol levels by the enzyme $11 \beta$-HSD II, which rapidly inactivates cortisol into cortisone. In the situation of cortisol resistance, cortisol levels are too high for the inactivational capacity of this enzyme. The number of patients diagnosed with cortisol resistance syndrome is low (i.e., $\approx$ nine) (Brufsky et al., 1990; Hurley et al., 1991; Karl et al., 1993,1996a; Malchoff et al., 1993; Ruiz et al., 2001; Mendonca et al., 2002; Vottero et al., 2002). Two mutations found in vitro could have been pre-existing acquired mutations in vivo, leading to Nelson syndrome and lupus nephritis (Karl et al., 1996b; Jiang et al., 2001). Most patients carried a mutation or defect in the ligand-binding domain; only one patient had a mutation in the DNA-binding domain (Lamberts, 2001). A possible explanation for the low number of patients is that a severe form of cortisol resistance is not compatible with life.

Hypersensitivity to endogenous cortisol has been described as well. Iida and colleagues (1990) reported a patient with symptoms of Cushing's syndrome, despite hypocortisolemia. Newfield and coworkers (2000) described a second patient with serious symptoms of Cushing's syndrome at peripubertal age but having normal cortisol levels. The lymphocytes of this second patient contained an increased number of GR per cell, with normal binding affinity. The molecular etiology of hyperreactivity to cortisol has not been clarified fully but two single-nucleotide polymorphisms of the $G R$ gene seem to play an important role in determining hypersensitivity. Figure 1 shows a schematic overview of the $G R$ gene, with locations of previously described mutations causing cortisol resistance and of polymorphisms shown to be associated with altered GC sensitivity. In contrast to the infrequent mutations, most polymorphisms are located in the N-terminal transactivation domain (Bray and Cotton, 2003). This review deals with these $G R$ gene polymorphisms, which were not only associated with differences in GC sensitivity but also related to differences in body composition and metabolic parameters. 


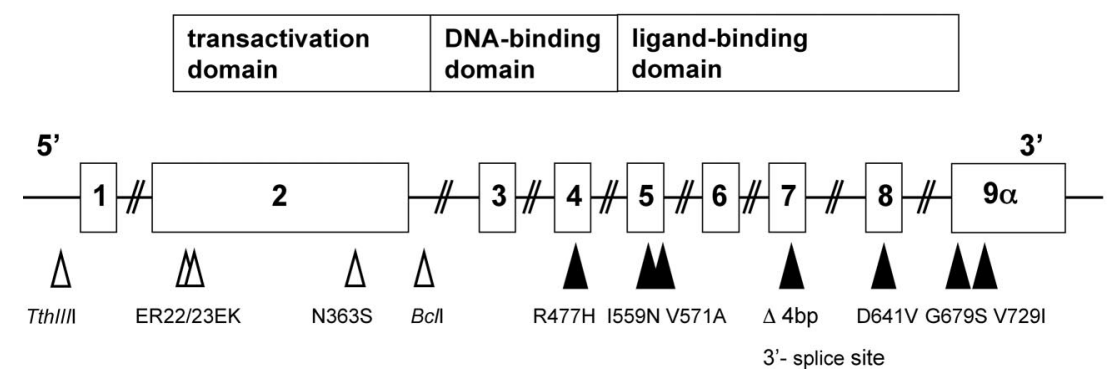

FIG. 1. Schematic overview of the GR gene, showing polymorphisms (white arrows), which have been shown to alter glucocorticoid (GC) sensitivity and are associated with differences in body composition, as well as mutations (black arrows) leading to the syndrome of cortisol resistance.

\section{The N363S Polymorphism of the GR Gene}

A polymorphism was identified in codon 363 of exon 2 of the $G R$ gene. Table I shows an overview of the associations with body mass index (BMI) and metabolic parameters found with this polymorphism.

This AAT $\rightarrow$ AGT nucleotide change results in an asparagine $\rightarrow$ serine amino acid change. It appeared in a group of 216 normal Dutch elderly individuals known to be associated with a higher sensitivity to GCs in vivo (Koper et al., 1997; Huizenga et al., 1998a). This was shown by lower cortisol levels after administration of $0.25-\mathrm{mg}$ DEX (Figure 2A) as well as a significantly greater decrease in cortisol levels (Figure 2B). Moreover, in this population, N363S carriers had an increased insulin response to exogenous DEX, which is likely to be related directly to their increased GC sensitivity. N363S carriers had a higher BMI and a tendency towards decreased bone mineral density in trabecular bone (Huizenga et al., 1998a; Lin et al., 1999). Lin and colleagues (1999) confirmed the association with BMI and even demonstrated an alleledosage effect on BMI (i.e., homozygous S-allele carriers had a higher BMI than heterozygous S-allele carriers). However, some controversy arose concerning the role of this polymorphism, as reviewed by Rosmond (2002). Dobson et al. (2001) found an increased waist-to-hip ratio in male N363S carriers but no associations with BMI, serum lipid levels, and glucose tolerance status in a Caucasian population. In three other reports, no association was observed between the N363S polymorphism and BMI (Halsall et al., 2000; Echwald et al., 2001; Rosmond et al., 2001). However, in a severely obese Italian population, the N363S variant was associated with increased BMI. Heterozygous carriers of both the N363S and the $B c l$ I polymorphism had higher cholesterol levels (Di Blasio et al., 2003). In a recent report by Lin and coworkers (2003b), the N363S variant was associated with coronary artery disease, independent of weight. $363 \mathrm{~S}$ allele 
TABLE I

Data from Six Studies That Investigated the Association Between the N363S Polymorphism of the Glucocorticoid Receptor (GR) Gene and Body Mass Index

\begin{tabular}{|c|c|c|}
\hline Reference & Population & $\begin{array}{l}\text { Associations with the N363S } \\
\text { polymorphism }\end{array}$ \\
\hline $\begin{array}{l}\text { Huizenga et al., } \\
\text { 1998a }\end{array}$ & 216 Dutch men and women & $\begin{array}{l}\text { Increased GC sensitivity, increased } \\
\text { insulin response to DEX, } \\
\text { increased BMI }\end{array}$ \\
\hline Lin et al., 1999 & $\begin{array}{l}195 \text { normotensive controls and } \\
124 \text { hypertensive subjects }\end{array}$ & Increased BMI, allele-dosage effect \\
\hline $\begin{array}{l}\text { Halsall et al., } \\
\qquad 2000\end{array}$ & 491 subjects & No association with BMI \\
\hline $\begin{array}{l}\text { Dobson et al., } \\
2001\end{array}$ & 135 men and 240 women & Increased WHR in men \\
\hline $\begin{array}{l}\text { Rosmond et al., } \\
\text { 2001b }\end{array}$ & 284 Swedish men & $\begin{array}{l}\text { No association with BMI, no } \\
\text { association with sensitivity } \\
\text { to GCs }\end{array}$ \\
\hline $\begin{array}{l}\text { Echwald et al. } \\
2001\end{array}$ & $\begin{array}{l}741 \text { obese Danish men and } 854 \\
\text { non-obese controls }\end{array}$ & $\begin{array}{l}\text { No association with BMI, WHR, or } \\
\text { weight gain }\end{array}$ \\
\hline $\begin{array}{l}\text { Lin et al., } \\
\quad 2003 b\end{array}$ & $\begin{array}{l}437 \text { Anglo-Celtic CAD patients } \\
\text { and } 302 \text { controls }\end{array}$ & $\begin{array}{l}\text { Association with CAD, elevated } \\
\text { cholesterol, triglycerides, total } \\
\text { cholesterol/HDL ratio }\end{array}$ \\
\hline $\begin{array}{l}\text { Lin et al., } \\
\quad 2003 \mathrm{a}\end{array}$ & $\begin{array}{l}951 \text { Anglo-Celtic/Northern } \\
\text { European subjects: } 152 \\
\text { obese, } 356 \text { type } 2 \text { diabetes, } \\
141 \text { hypertensive, } 302 \\
\text { controls }\end{array}$ & $\begin{array}{l}\text { Association with obesity and } \\
\text { overweight in several patient } \\
\text { settings but no association with } \\
\text { hypertension or type } 2 \text { diabetes }\end{array}$ \\
\hline $\begin{array}{l}\text { Di Blasio et al., } \\
2003\end{array}$ & 185 obese women, 94 obese men & $\begin{array}{l}\text { Increased BMI, interaction with the } \\
B c l \text { I polymorphism: higher } \\
\text { cholesterol levels }\end{array}$ \\
\hline
\end{tabular}

[Abbreviations: BMI, body mass index; CAD, coronary artery disease; DEX, dexamethasone; GC, glucocorticoid; HDL, high-density lipoprotein-cholesterol; WHR, waist-to-hip ratio.]

frequency was particularly high in patients with angina pectoris. In this population of Anglo-Celtic descent, several atherosclerosis risk factors were associated with the N363S variant: increased cholesterol and triglyceride concentrations and a higher total cholesterol/high-density lipoprotein (HDL) cholesterol ratio. The same authors showed an association between the N363S polymorphism and 
A

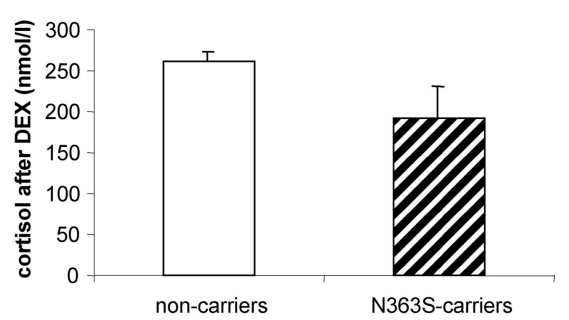

C

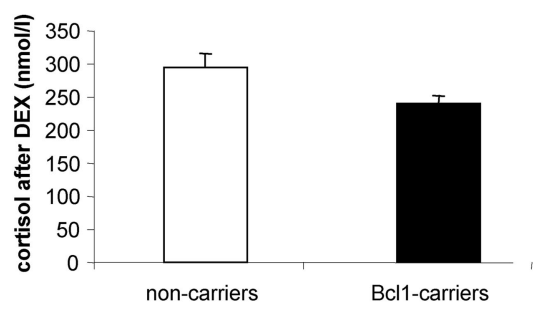

$E$

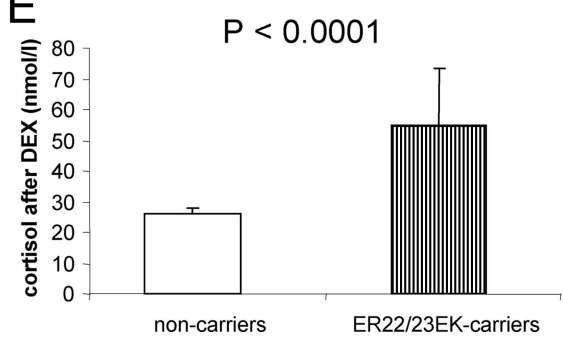

B

$P<0.05$
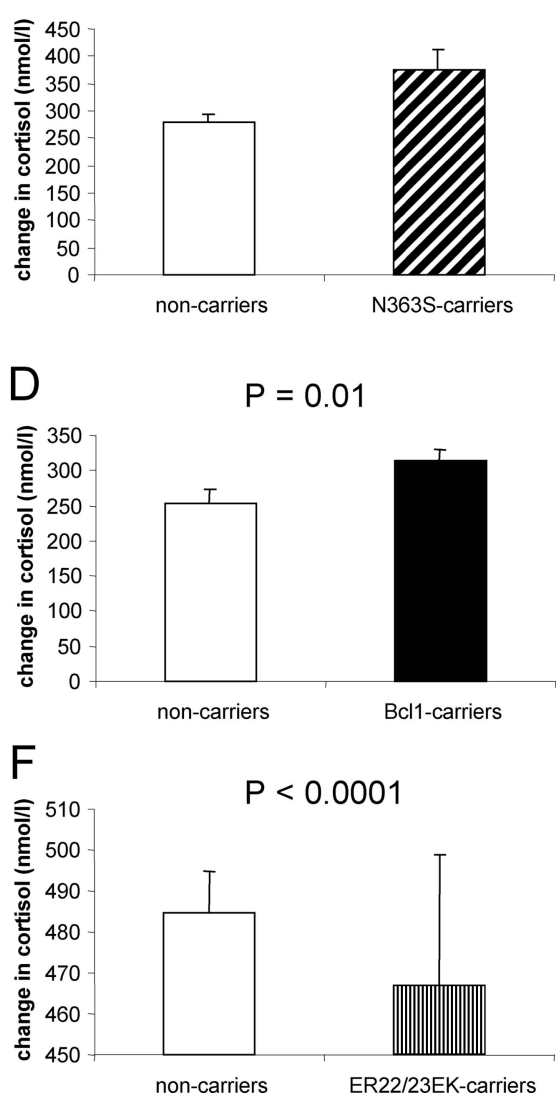

FIG. 2. Cortisol levels (nmol/l) after dexamethasone (DEX) suppression tests (graphs on the left: A, C, E) and absolute change in cortisol (nmol/l) after DEX (graphs on the right: B, D, F). Results from a 0.25 -mg DEX suppression test are shown for N363S and BclI carriers. Data concerning a 1-mg test are shown for ER22/23EK carriers. (A \& B) Noncarriers (white bars) were compared to N363S carriers (striped bars). Lower post-DEX cortisol and greater decrease in N363S carriers suggest a hypersensitivity to GCs. (C \& D) Heterozygous and homozygous $B c l$ I G-allele carriers (black bars), also lower post-DEX cortisol and greater decrease in $B c l$ I G-allele carriers, suggesting that $B c$ II G-allele carriers are hypersensitive to GCs. (E \& F) ER22/23EK carriers (vertically striped bars), who had higher cortisol levels after 1-mg DEX and a smaller decrease in cortisol, which suggests that the ER22/23EK variant is associated with a relative resistance to GCs.

obesity as well as overweight in several groups of patients (Lin et al., 2003a). However, no association was found with hypertension or type 2 diabetes. Interestingly, in a Japanese as well as in a Chinese population, the N363S variant did not occur (Ikeda et al., 2001; Lei et al., 2003). 
Figure 3 shows the DEX concentrations necessary to achieve 50\% of the maximal inhibition (IC50) in mitogen-induced, in vitro cell proliferation assays in noncarriers and N363S carriers (Huizenga et al., 1998a). A trend was observed towards a lower IC50 in carriers of the N363S polymorphism, which supports the observation of increased sensitivity to GCs in vivo. We have to take in to account that in the group of noncarriers (left dots in Figure 3), carriers of the very frequent $B c l$ I polymorphism are present. This polymorphism has been associated with increased GC sensitivity. As a consequence, differences in IC50 in Figure 3 between "real noncarriers" (i.e., noncarriers of both N363S and BclI) and N363S carriers probably are underestimated. This underestimation might apply to other studies comparing noncarriers and N363S in body composition and metabolic parameters.

The exact mechanism underlying increased sensitivity to GCs is unknown. In in vitro expression experiments using a mouse mammary tumor virus-driven/ luciferase expression (MMTV-LUC) system, no differences were observed

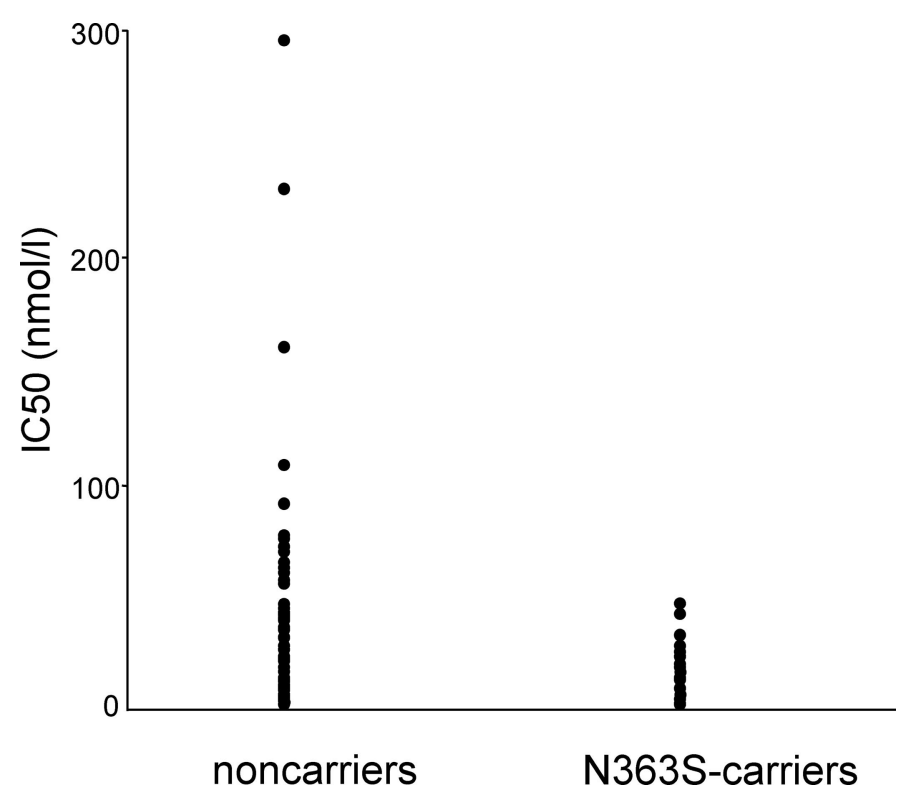

FIG. 3. Concentrations of DEX necessary to achieve 50\% of the maximal inhibition (IC50) in mitogen-induced peripheral mononuclear cell proliferation assays in noncarriers and carriers of the N363S polymorphism. A trend was observed towards a lower mean IC50 in N363S carriers, compared to noncarriers. [Adapted with permission from Huizenga NA, Koper JW, De Lange P, Pols HA, Stolk RP, Burger H, Grobbee DE, Brinkmann AO, De Jong FH, Lamberts SW 1998 A polymorphism in the glucocorticoid receptor gene may be associated with and increased sensitivity to glucocorticoids in vivo. J Clin Endocrinol Metab 83:144-151. Copyright The Endocrine Society.] 
between the N363S variant GR and wild-type GR in efficacy to activate transcription (de Lange et al., 1997). However, Feng and colleagues (2000) suggested that the N363S variant modulated the phosphorylation state of the GR and might alter interactions with other transcription factors. No evidence for this hypothesis has been found. However, in two reports, GR hyperactivity was induced by in vitro-created mutants, resulting in increased transcriptional activity and a diminished capacity to repress activator protein-1 (AP-1) induction (Heck et al., 1994; Guido et al., 1996).

\section{The BclI Polymorphism of the GR Gene}

Murray et al. (1987) reported an intronic restriction fragment length polymorphism (RFLP) of the GR gene, which was described as consisting of a short fragment of $2.3 \mathrm{~kb}$ and a large fragment of $4.5 \mathrm{~kb}$. Since then, several association studies have been performed to investigate the role of this variant in obesity, using Murray's terminology and technique. Recently, we identified the exact nucleotide alteration: a $\mathrm{C} \rightarrow \mathrm{G}$ mutation, 646 nucleotides downstream from exon 2, which results in fragments of $2.2 \mathrm{~kb}$ and $3.9 \mathrm{~kb}$ (van Rossum et al., 2003b). The $\mathrm{C}$ allele is the most-frequently occuring and thus can be considered the wild-type allele (Table II). Table III displays an overview of reports of the $B c l$ I polymorphism and its associations with body composition and metabolic parameters.

The first association study of the $B c l$ I polymorphism, decribed by Weaver and coworkers (1992), showed no differences in BclI polymorphism frequency between an obese and a normal-weight population. However, within the obese group, homozygous G-allele $(4.5 \mathrm{~kb})$ carriers had higher insulin levels and were

TABLE II

Fragments Length of the BclI and the TthIIII Restriction Fragment Polymorphism and Their Corresponding Nucleotide Changes as Well as Allelic Frequencies

\begin{tabular}{llll}
\hline RFLP & $\begin{array}{l}\text { Length restriction } \\
\text { fragment }^{\mathrm{a}}\end{array}$ & Nucleotide change & $\begin{array}{l}\text { Allele } \\
\text { frequency }\end{array}$ \\
\hline$B c$ II & $2.3 \mathrm{~kb}$ & $\mathrm{C}$ & $65 \%$ \\
& $4.5 \mathrm{~kb}$ & $\mathrm{G}$ & $35 \%$ \\
TthIIII & $3.4 \mathrm{~kb}$ & $\mathrm{C}$ & $62 \%$ \\
& $3.8 \mathrm{~kb}$ & $\mathrm{~T}$ & $38 \%$ \\
\hline
\end{tabular}

${ }^{a}$ Fragment length as described in literature. After identification of the exact nucleotide change, we found that the fragments of the $B c l$ I polymorphism were $2.2 \mathrm{~kb}$ and $3.9 \mathrm{~kb}$, respectively. ${ }^{\mathrm{b}}$ Allele frequency as observed in a subset of subjects from the Rotterdam study, a population-based study in the elderly. RFLP, restriction fragment length polymorphism. 
TABLE III

Data from Studies That Involved the BclI Polymorphism of the GR Gene and Investigated Whether Differences Existed Between CC Carriers, CG Carriers, and GG Carriers in Body Composition, Blood Pressure, and Metabolic Parameters

\begin{tabular}{|c|c|c|}
\hline Reference & Population & $\begin{array}{l}\text { Associations with the } \mathrm{G} \text { allele of the } B c l \mathrm{I} \\
\text { polymorphism }\end{array}$ \\
\hline $\begin{array}{l}\text { Weaver et al., } \\
1992\end{array}$ & $\begin{array}{l}56 \text { Obese and } 43 \text { non-obese } \\
\text { premenopausal women }\end{array}$ & $\begin{array}{l}\text { Hyperinsulinemia in obese GG carriers but not } \\
\text { in non-obese GG carriers, no association } \\
\text { of the G allele with obesity }\end{array}$ \\
\hline Watt et al., 1992 & $\begin{array}{l}864 \text { Adults (aged 16-24 } \\
\text { years) and their parents }\end{array}$ & $\begin{array}{l}\text { Homozygosity for the } \mathrm{G} \text { allele was more } \\
\text { frequent in the group with personal and } \\
\text { parental hypertension }\end{array}$ \\
\hline $\begin{array}{l}\text { Clement et al., } \\
1996\end{array}$ & 80 Obese families & $\begin{array}{l}\text { Tendency towards linkage between the } B c l \text { I } \\
\text { marker and obesity (BMI }>27) \text {, no } \\
\text { association after replication }\end{array}$ \\
\hline $\begin{array}{l}\text { Panarelli et al., } \\
1998\end{array}$ & 64 Men (aged 18-40 years) & $\begin{array}{l}\text { No association of the G-allele with BMI, } \\
\text { increased in vivo sensitivity to } \\
\text { budesonide in GG-carriers }\end{array}$ \\
\hline $\begin{array}{l}\text { Buemann et al., } \\
\quad 1997\end{array}$ & $\begin{array}{l}79 \text { Men and } 73 \text { women, } \\
\text { middle-aged }\end{array}$ & $\begin{array}{l}\text { Increased abdominal visceral fat in lean GG } \\
\text { carriers but not in overweight GG } \\
\text { carriers }\end{array}$ \\
\hline $\begin{array}{l}\text { Rosmond et al., } \\
\quad 2000\end{array}$ & 262 Swedish men & $\begin{array}{l}\text { Increased abdominal obesity and higher } \\
\text { cortisol levels in GG carriers compared } \\
\text { to CC carriers }\end{array}$ \\
\hline $\begin{array}{l}\text { Ukkola et al., } \\
\text { 2001b }\end{array}$ & $\begin{array}{l}12 \text { Pairs of monozygotic lean } \\
\text { male twins (aged } 21 \\
\text { years) }\end{array}$ & $\begin{array}{l}\text { CC carriers had a greater increase in weight, } \\
\text { abdominal visceral fat, and cholesterol } \\
\text { levels in response to overfeeding } \\
\text { compared to CG carriers }\end{array}$ \\
\hline $\begin{array}{l}\text { Ukkola et al., } \\
\text { 2001a }\end{array}$ & $\begin{array}{l}322 \text { Men and } 420 \text { women } \\
\text { (aged } 42 \text { years) }\end{array}$ & $\begin{array}{l}\text { G allele associated with abdominal visceral } \\
\text { fat and gene-gene interactions present } \\
\text { with lipoprotein lipase gene and } \\
\text { adrenergic receptor gene }\end{array}$ \\
\hline $\begin{array}{l}\text { Tremblay et al., } \\
2003\end{array}$ & $\begin{array}{l}90 \text { Male and } 83 \text { female } \\
\text { adolescents }\end{array}$ & $\begin{array}{l}\text { Female CG carriers had a greater increase in } \\
\text { subcutaneous fat mass during a 12-year } \\
\text { follow-up than CC carriers or GG } \\
\text { carriers. No differences were found in } \\
\text { males }\end{array}$ \\
\hline $\begin{array}{l}\text { van Rossum et al., } \\
\quad 2003 \mathrm{c}\end{array}$ & $\begin{array}{l}197 \text { Dutch elderly subjects, } \\
1963 \text { elderly males and } \\
\text { females, } 400 \text { elderly } \\
\text { males }\end{array}$ & $\begin{array}{l}\text { G allele associated with hypersensitivity to } \\
\text { both 1-mg and } 0.25 \text {-mg dexamethasone } \\
\text { (in an allele-dosage way), lower BMI, } \\
\text { and a tendency towards lower lean } \\
\text { mass, while fat mass was not different }\end{array}$ \\
\hline
\end{tabular}

CC carriers, in previous reports, were described as homozygous $2.3 \mathrm{~kb}$-allele carriers, CG carriers as heterozygous $2.3 / 4.5 \mathrm{~kb}$ carriers, and GG carriers as homozygous $4.5 \mathrm{~kb}$-allele carriers. 
more insulin resistant, when compared to a group consisting of CC (homozygous $2.3 \mathrm{~kb})$ and CG (2.3/4.5 kb) carriers. In a report by Panarelli et al. (1998), no association between the G allele and BMI was described. However, increased skin vasoconstriction was observed in homozygous G-allele carriers after injection with budesonide, a synthetic GC, which suggests increased in vivo sensitivity to GCs. In contrast, this study showed that the in vitro affinity and sensitivity of leucocytes to DEX tended to be lower. Although these findings were not statistically significant, they suggest that this polymorphism might have tissue-specific effects. Three other reports, all in middle-aged individuals, showed an association between the BclI polymorphism and abdominal visceral obesity but not general obesity (Buemann et al., 1997; Rosmond et al., 2000b; Ukkola et al., 2001a). GCs are known to induce central obesity, as observed in Cushing's disease. It is not known whether this polymorphism is associated with other features of Cushing's (e.g., easy bruising). However, the relationship between abdominal obesity and the $B c l$ I polymorphism suggests a greater effect of GCs due to alterations at the level of the GR, in particular, in visceral fat. This was confirmed in an elderly Dutch population of 197 subjects with a mean age of 67 years (van Rossum et al., 2003b). The carriers of the G allele of the BclI polymorphism showed a greater suppression after 1-mg DEX as well as after 0.25 -mg DEX (Figure 2D). This association was observed in an allele-dosage way and suggests a hypersensitivity to GCs with respect to the negative-feedback mechanism at the pituitary level. In a subset of 1963 subjects of the Rotterdam study, effects of the $B c l$ I variant on body composition in the elderly were further assessed (van Rossum et al., 2003b). The effects appeared to be the opposite of those reported at a younger age: lower BMI in G-allele carriers. To further explore whether this lower BMI was due to a smaller amount of fat mass or less lean mass, we investigated an independent group of 370 Dutch males with a mean age of 78 years (van Rossum et al., 2003b). Again, we observed a lower BMI in G-allele carriers. We did not find differences in fat mass, although lean mass tended to be lower in G-allele carriers in an allele-dosage way. Thus, the slightly lower lean mass is in line with the previously observed hypersensitivity to GCs in G-allele carriers. This suggests that, at an older age, lower BMI possibly can be ascribed to muscle atrophy, which occurs in all healthy elder individuals, but seems more pronounced in carriers of the $\mathrm{G}$ allele of the $B c l \mathrm{I}$ variant than in noncarriers.

In an 100-day experiment conducted with 12 pairs of monozygotic twins at young-adult age, effects of the $B c l$ I variant were studied in relation to body composition and metabolic changes in response to overfeeding (Ukkola et al., 2001b). In this study, no homozygous G-allele carriers were found. In contrast with these findings, $\mathrm{CC}$ carriers experienced a greater increase in body weight, visceral fat, and cholesterol levels after overfeeding than CG carriers. However, another study in adolescents showed that female heterozygous CG-allele carriers 
experienced a greater increase in subcutaneous fat, as measured by skinfold, when compared to both homozygous CC carriers and GG carriers during a 12-year follow-up period (Tremblay et al., 2003). No differences were found in baseline or post-follow-up subcutaneous fat mass, total fat mass, or, importantly, trunk fat mass. The authors speculated that one mutated allele could have a different effect than two mutated alleles. In the latter state, an alternative pathway might be switched on to compensate for changes resulting from two polymorphic alleles. Mechanisms supporting this theory have been reported in mouse models involving cyclooxygenase-2 and glucose transporter-4 genes (Stenbit et al., 1997; Fain et al., 2001). The results of Trembley et al. are not in line with the allele-dosage associations between the $B c l$ I polymorphism and hypersensitivity to GCs and BMI that we observed in our large elderly populations (van Rossum et al., 2003b). However, at baseline, they show that female homozygous GG carriers tend to have more subcutaneous fat than CC carriers and CG carriers. Although this difference was not statistically significant, it might explain why they did not find an even greater increase in GG carriers than in CG carriers during follow-up. Thus, in this study, the GG carriers might already have been slightly fatter at preadolescent age.

The molecular mechanism of the BclI polymorphism has not been clarified. It is likely that this intronic polymorphism exerts its effects in a different way than the N363S polymorphism. No alterations in glucose and insulin metabolism have been observed in carriers of the $B c l$ I polymorphism within the normal-weight population, while N363S carriers clearly showed an increased insulin response to DEX. Only in obese carriers of the $B c l$ I polymorphism were hyperinsulinemia and relative insulin resistance observed. However, no transfection experiments are possible to elucidate the mechanism, since the $B c l I$ polymorphism is located in an intron. We cannot rule out the possibility that this intronic polymorphism is linked to another polymorphism in the promoter region of the $G R$ gene, which could result in increased GR expression or a variant in the $3^{\prime}$-untranslated region, which could increase stability of mRNA. However, we did not observe any linkage to the polymorphisms reviewed here (data not shown). Another possibility could be linkage to another gene in the vicinity of the $G R$ gene. Since in most studies, the $B c l$ I polymorphism shows clear associations with increased sensitivity to GCs, this possibility is less likely. It is also known that intronic variations can influence the splicing process. However, the point mutation in the $B c l$ I site is not located near a regulatory splice site.

In summary, contrasting data have been reported about the $B c l$ I polymorphism with respect to its association with body composition. A possible explanation is that hypersensitivity to GCs due to the $B c l$ I polymorphism has different consequences during life. It might be that early in life, fat mass - particularly abdominal fat — is predominantly affected (i.e., BclI G-allele carriers have more 
fat), whereas later in life, the most-pronounced effects are observed on lean mass (i.e., BclI G-allele carriers have lower lean mass).

\section{The ER22/23EK Polymorphism of the GR Gene}

In a previous report, we described a polymorphism consisting of two linked, single-nucleotide mutations in codons 22 and 23 (exon 2 of the GR gene) (Koper et al., 1997). The first mutation in codon 22 did not result in an amino acid change (GAG $\rightarrow$ GAA, both coding for a glutamic acid (E)) but the mutation in codon 23 (AGG $\rightarrow$ AAG) caused a change from arginine $(\mathrm{R})$ to lysine $(\mathrm{K})$. In a population of 202 randomly selected individuals from the Rotterdam study, a population-based cohort study in the elderly, we found an association with higher post-DEX cortisol levels (Figure 2E) as well as less cortisol suppression after a 1-mg DEX suppression test in ER22/23EK carriers (Figure 2F). This finding suggests a relative GC resistance (van Rossum et al., 2002). In the same group having a mean age of 67 years, we found that carriers of the ER22/23EK variant had lower fasting insulin levels and increased insulin sensitivity (Figure 4). Carriers of the ER22/23EK polymorphism also had lower total and low-density lipoprotein cholesterol levels (Figure 5).

These findings of lower cholesterol and insulin levels were both confirmed during a second measurement performed 2.5 years later. This suggests that ER22/23EK carriers have a lower tendency to develop impaired glucose tolerance, type 2 diabetes, or cardiovascular disease. In line with these favourable metabolic parameters, ER22/23EK polymorphism frequency was significantly
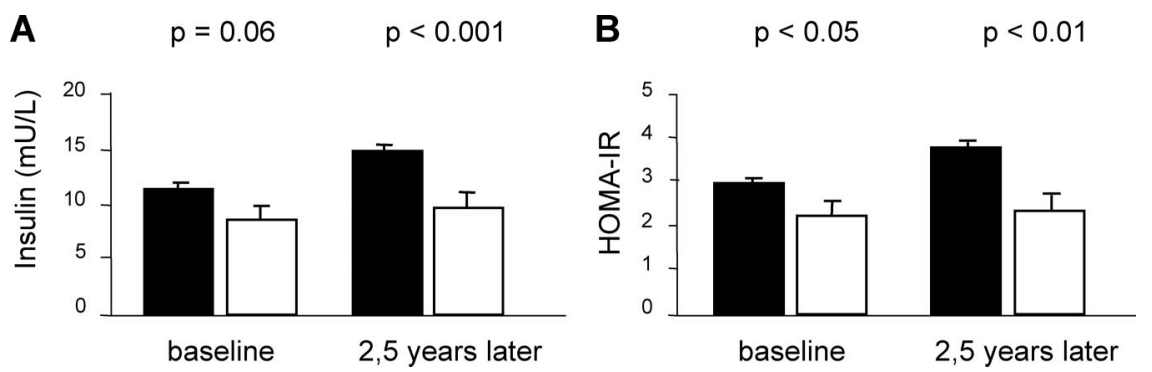

FIG. 4. (A) Fasting insulin concentrations in noncarriers and ER22/23EK carriers at first examination. Insulin concentrations tended to be lower in ER22/23EK carriers compared to noncarriers $(\mathrm{p}=0.06)$. On the right, fasting insulin concentrations in noncarriers and ER22/23EK carriers at second examination (2.5 years later). Fasting insulin concentrations were significantly lower in ER22/23EK carriers $(\mathrm{p}<0.001)$. (B) Homeostasis model assessment-insulin resistance (HOMA-IR) scores (index of insulin resistance) at baseline and at second examination 2.5 years later in noncarriers and ER22/23EK carriers. At both measurements, ER22/23EK carriers were significantly less insulin resistant. 

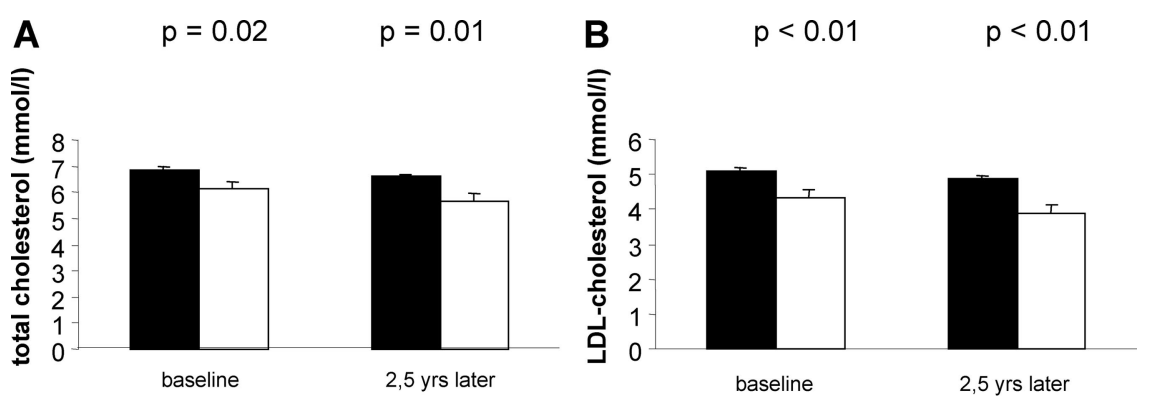

FIG. 5. Total cholesterol (A) and low-density lipoprotein (LDL) cholesterol concentrations (B) in noncarriers and ER22/23EK carriers at first examination. On the right side of each figure, cholesterol concentrations in noncarriers and ER22/23EK carriers at second examination (2.5 years later) are shown. At all measurements, ER22/23EK carriers had significantly lower total and LDL-cholesterol levels than noncarriers.

higher in the oldest half of the studied population. To further explore whether there is an effect on survival at elder age of this polymorphism, we studied a population of 402 men with a mean age of 77 years (van Rossum et al., 2004a). After a follow-up of 4 years, $78(19.2 \%)$ of the noncarriers died, while none of the 21 heterozygous ER22/23EK carriers died, a statistically significant difference. It is has been shown that high C-reactive protein (CRP) is related to increased risk of cardiovascular events (Liuzzo et al., 1994; Thompson et al., 1995; Haverkate et al., 1997). In this population, it was shown that CRP and interleukin-6 (IL-6) were strong predictors of survival (Feelders et al., 2003). We found no differences in IL-6 levels between carriers and noncarriers of the ER22/23EK variant; however, CRP levels were significantly lower in ER22/ 23EK carriers (van Rossum et al., 2004a). This suggests that carriers of the ER22/23EK variant are relatively protected from vascular damage. Furthermore, total and LDL-cholesterol levels tended to be lower in ER22/23EK carriers, although this did not reach statistical significance. All these data together suggest that the better survival in ER22/23EK carriers might be due to a healthier metabolic profile.

We also studied the effects of this polymorphism at a younger age by investigating a cohort of 350 male and female subjects, who were followed from the age of 13 until the age of 36 years. We studied whether anthropometric parameters and body composition differed between ER22/23EK genotypes (van Rossum et al., 2004b). In males aged 36 and 32 years, we found ER22/23EK carriers to be, on average, $5 \mathrm{~cm}$ taller. Although there were no differences in BMI or fat mass, lean body mass was significantly higher in male carriers of the ER22/23EK variant. In accordance, their muscle strength, as measured by arm pull tests and high jump from standing, also was significantly greater. These 
differences tended to be already present during puberty but reached statistical significance only at young-adult age.

In females, different associations were observed with the ER22/23EK variant. Waist circumferences tended to be smaller in female ER22/23EK carriers at young-adult age but no differences in BMI were found. It is known that GCs negatively affect muscle mass and induce abdominal obesity. Thus, at youngadult age, the ER22/23EK variant is associated with beneficial changes in body composition, which can possibly be explained by a relative resistance to GCs in these tissues. In addition, effects of the ER22/23EK polymorphism seem to be gender specific.

It is known that GCs influence important brain structures and a normal level of cortisol is critical for many cerebral functions. In humans, high cortisol levels have been found to result in decreased hippocampal formation volume and memory impaiment (Starkman et al., 1992; Lupien et al., 1997). Disturbances in the HPA axis have been found to be related to dementia disorders (Weiner and Lourie, 1968; Gottfries et al., 1994; Nasman et al., 1995) In a large, populationbased study in the elderly, we studied whether the ER22/23EK polymorphism was associated with hippocampal volume, dementia, and white matter lesions. We found that ER22/23EK carriers had a lower risk of dementia as well as fewer white matter lesions in the brain (van Rossum et al., 2003a). In addition, the ER22/23EK polymorphism was associated with better performance on psychomotor speed tests. It has been shown that white matter lesions are associated with small vessel disease (Bots et al., 1993; Breteler et al., 1994). Thus, this association might be a direct result of the beneficial effects of the ER22/23EK polymorphism on metabolic risk factors for atherosclerosis. No associations were found between the ER22/23EK variant and hippocampal volume. This might be explained by the fact that, in basal conditions, most effects on the hippocampus are mediated by the MR, while the GR plays a major role only in the activated state (e.g., physical or psychological stress) (De Kloet and Reul, 1987). In other parts of the brain, the GR is more important for mediating effects of GCs, so the observed associations with dementia might be explained by a smaller direct effect of GCs on the brain due to a relative GC resistance.

The mechanism that explains the effects of this polymorphism is under study. Several possibilities exist through which this variation of the $G R$ gene can lead to these effects. Since the ER22/23EK polymorphism is located in the transactivation domain, the arginine to lysine amino acid change might affect the receptor's tertiary structure, influencing the transactivational and/or transrepressional activity on target genes (de Lange et al., 1997; Russcher et al., 2003). Recently, it has been shown that two different methionine (M) codons in GR mRNA may be used as the initiation codon: M1 and M27, resulting in two isoforms, GR-A and GR-B, respectively. The GR-B protein has a stronger transactivating effect in transient transfection experiments but no difference in 
transrepression (Yudt and Cidlowski, 2001). The nucleotide changes associated with the ER22/23EK polymorphism might affect the secondary structure of the GR mRNA, thus influencing the choice of initiation codon. Indeed, secondary structure prediction (M-fold) showed different structures for the wild-type and polymorphic mRNA. Another possible explanation for the decreased GC sensitivity might be that the GR transactivational activity is affected by a different GR-A/GR-B ratio (Russcher et al., 2003). A third option is that the ER22/23EK variant might change mRNA stability, which is maintained when proteins responsible for this stability bind to the mRNA molecule. If the polymorphic mRNA recruits proteins in a different way, mRNA stability is affected, which might be a clue for the decreased GC sensitivity in ER22/23EK carriers.

In summary, the ER22/23EK polymorphism of the $G R$ gene is associated with a relative $\mathrm{GC}$ resistance and a healthier metabolic condition, as evidenced by lower cholesterol levels and increased insulin sensitivity. Furthermore, this variant is associated with a beneficial body composition at young age and leads to a lower risk of dementia and better survival in the elderly.

\section{The TthIIII Polymorphism of the GR Gene}

In the GR gene promoter region, a TthIIII RFLP previously was reported by Detera-Wadleigh and colleagues (1991). Rosmond et al. (2000a) showed this polymorphism to be associated with elevated diurnal cortisol levels in a population of 284 Swedish men. No relationships were found between the TthIIII variant and anthropometry, glucose, and insulin metabolism or lipid spectrum. We recently identified the location of the nucleotide change: a C/T change, 3807 bp upstream of the GR mRNA start (Table II).

In the same subpopulation of the Rotterdam study in which we studied the relationship between the three other polymorphisms described in this review and feedback sensitivity to GCs, we investigated whether an association existed between the TthIII polymorphism and GC sensitivity (E.F.C. van Rossum, P. Roks, F.H. de Jong, A.O. Brinkmann, H.A.P. Pols, J.W. Koper, S.W.J. Lamberts, unpublished data). In this group, we found $39.7 \% \mathrm{CC}$ carriers, $44.5 \% \mathrm{CT}$ carriers, and $15.8 \%$ TT carriers. No differences were found in cortisol levels between the TthIIII genotypes before and after 1-mg and 0.25-mg DEX suppression, nor in anthropometric parameters, glucose and insulin levels, or cholesterol concentrations. We also studied whether this TthIIII polymorphism interacted with the N363S, BclI, and ER22/23EK polymorphisms. No interactions with $\mathrm{N} 363 \mathrm{~S}$ or $B c l$ I were found. Interestingly, however, all carriers of the ER22/23EK polymorphism carried the TthIIII T variant. This T allele of the TthIII polymorphism is very common and exists without the ER22/23EK variant being present. To study the effects of carrying the TthIIII $\mathrm{T}$ allele and the ER22/23EK polymorphism, we compared the following three groups: 1) noncarriers of both 
polymorphisms (TthIIII CC and ER22/23ER); 2) carriers of one variant allele of the TthIIII polymorphism (TthIIII CT/TT and ER22/23ER); and 3) carriers of both polymorphisms (TthIIII CT/TT and ER22/23EK). The latter group had a significantly reduced cortisol response to 1-mg DEX as well as lower insulin and cholesterol levels, compared to the two other groups. No differences were found between the group of noncarriers of both polymorphisms and the group of carriers of only the TthIIII T variant. This suggests that the TthIIII polymorphism is not functional by itself; it might be functionally relevant only in combination with ER22/23EK. We do not know whether the TthIIII variant at the $5^{\prime}$-flanking region of the $G R$ gene is essential in the associations of the ER22/23EK polymorphism or if its presence at the same allele is coincidence and does not influence the effects of the ER22/23EK variant. Possibly, the associations Rosmond and coworkers (2000a) found between alterations in cortisol levels and the TthIIII polymorphism could be explained by the presence of the ER22/23EK variant. However, no data have been published on the ER22/23EK polymorphism in this Swedish population.

\section{Discussion}

This review focused on several $G R$ gene polymorphisms that were associated with body composition and metabolic parameters. As shown in Figure 1, the three functional polymorphisms are located in exon 2 (transactivating domain) and intron 2. This is in contrast to the previously described rare mutations causing the syndrome of GC resistance, which are located predominantly in the ligand-binding domain. GCs are essential for many regulatory processes in the human body, so a mutation leading to an absolute resistance to GCs is not compatible with life. The previously described patients, carrying a mutation of the $G R$ gene, have decreased negative feedback at the level of the pituitary gland, which leads to HPA axis hyperactivation. Many of the symptoms found in patients with GC resistance are the consequence of this compensatory increased HPA axis activity: hyperandrogenism (in particular, leading to symptoms in females and children before puberty) and increased mineralocorticoid effects. The latter are due to exposure of the MR to high concentrations of cortisol, which cannot be effectively inactivated by $11 \beta$ HSD II.

Polymorphisms, common variations at the DNA level occurring in the normal population with a frequency of more than $1 \%$, have much more-subtle effects. However, because of their high frequency in the population, their impact may be much greater. In several - but not all - studies, polymorphisms in the $G R$ gene described here seem to correlate significantly with variation of sensitivity to endogenous GCs in normal individuals. Table IV overviews the four discussed polymorphisms and their relation with altered GC sensitivity. The N363S and BclI polymorphisms both were associated with hypersensitivity to 
TABLE IV

Four Polymorphisms of the GR Gene, Studied in the Same Population in Relation to Glucocorticoid Sensitivity

\begin{tabular}{lllll}
\hline Polymorphism & BclI & N363S & ER22/23EK & TthIIII \\
\hline $\mathrm{N}$ & 191 & 216 & 202 & 205 \\
Fasting cortisol & ND & ND & ND & ND \\
Sensitivity to 1-mg DEX & Increased & ND & Decreased & ND \\
Sensitivity to 0.25-mg DEX & Increased & Increased & ND & ND \\
\hline
\end{tabular}

[Abbreviations: N, number; DEX, dexamethasone; ND, no differences between genotype groups of the above-mentioned polymorphism.]

GCs, while the ER22/23EK polymorphism was associated with relative resistance to GCs. No associations were found with the TthIIII polymorphism. However, the ER22/23EK variant was found to be linked to the TthIIII polymorphism. In this respect, associations with GC resistance and beneficial metabolic profile (i.e., low insulin and cholesterol levels) were observed in carriers of both the ER22/23EK and TthIIII polymorphisms. Considering DEX suppression test outcomes in carriers of the three functional polymorphisms, it seems that the 0.25-mg DEX suppression test is most sensitive to detect hypersensitivity to GCs, while the 1-mg DEX suppression test may be more suitable to detect a relative resistance to GCs.

Study of clinical associations of polymorphisms has several limitations. In particular, when studies are performed in rather small populations, the risk that the observed associations are based on coincidence will be increased. It is also known that the general frequency of polymorphisms varies greatly between ethnic populations. Thus, results from one population do not necessarily apply to others. For example, the N363S polymorphism has been reported in Australia with an allele frequency of 7.4\% (Lin et al., 1999), whereas in two Asian studies (Ikeda et al., 2001; Lei et al., 2003), no N363S carriers were found. Effects of polymorphisms may differ between races, due to different combinations of polymorphisms of several genes. Differences in environmental factors also play an important role. In this respect, association studies performed in nonhomogeneous populations are difficult to interpret. Within similar ethnic populations, observed associations with $G R$ gene polymorphisms vary, which can be caused by differences in characteristics of the study populations, environmental or socioeconomic factors, or differences between generations. Furthermore, it is known that in large population studies, unintended errors in data collection or misclassifications occur relatively frequently, which can influence outcomes. A limitation of $G R$ gene polymorphism studies is that no in vitro mechanisms have been clarified, while many associations have been found in vivo. 
Observed associations with altered GC sensitivity may contribute to a better understanding of the variations in regulation of the HPA axis between normal individuals. Previous data suggest that the HPA axis setpoint in humans might be genetically determined, since the intra-individual variations in post-DEX cortisol concentrations are rather small (Huizenga et al., 1998b).

These GR gene polymorphisms may have modifying effects on conditions such as (hereditary) atherosclerosis. It is known that some individuals survive until a great age, although they have very high cholesterol levels (WeverlingRijnsburger et al., 1997). Thus, they might be protected by a genetic variant such as the ER22/23EK. On the other hand, individuals who carry the N363S or the $B c l$ l polymorphism might be more at risk for cardiovascular disease. The N363S variant recently was found to be associated with coronary artery disease, independent of obesity, as well as with increased total cholesterol and triglyceride concentrations and an elevated total cholesterol/HDL ratio. Both the N363S and the $B c l$ I polymorphism may predispose to obesity. However, as is well known, environmental, dietary, and socioeconomic factors are also important determinants of the obesity phenotype. Associations with polymorphisms depend on many additional factors: differences in characteristics between populations, prevalence of the polymorphism, and interactions with other genetic polymorphisms. These factors, taken together, might explain the discrepancies between studies so far encountered.

In clinical practice, GCs are used widely to treat diseases (e.g., asthma, chronic inflammations, prevention of rejection of organ transplants) as well as replacement therapy. It is well known that effects of GC treatment vary considerably between patients. Some patients respond very well to therapeutical administration of GCs but also develop serious side effects, while others need a very high dose to establish any clinical effect and do not suffer from side effects. The response to GCs in the majority of patients lies between these extremes. It is likely that these polymorphisms are to some extent responsible for the variability in response to therapeutically used GCs. In the future, after appropriate additional research, it might be useful to screen for the presence of these $G R$ gene variants, in order to determine an individual's dose of GCs. This dose should be adjusted to a person's need, taking into account the genetically determined GC sensitivity, in such a way that it is therapeutically effective but does not cause side effects. We do not know whether the altered sensitivity associated with these polymorphisms differs for various types of clinically used GCs and whether the manner of application (e.g., local, systemic) influences the effects of the polymorphisms.

During evolution, a selection process occurred in which some de novo mutations probably had beneficial effects and slowly became more frequent in the population. We found that the ER22/23EK variant in males was associated with greater lean mass and muscle strength. In this view, the ER22/23EK 
polymorphism could have resulted in strong individuals with a greater chance to survive due to an advantage in food-collecting and fighting ability. The N363S and $B c l$ I carriers may have had advantages for survival through their tendency to accumulate fat, which was especially favorable in times of food deficit. In this respect, the $B c l I$ polymorphism probably arose long ago, since the allele frequency in normal population is very high. However, in modern times of food abundance, combined with increased psychological stress and lack of exercise, the N363S and BclI polymorphisms may have turned into a disadvantage. An increased sensitivity to GCs, resulting in fat accumulation, is probably a risk factor in atherosclerosis. This is supported by the findings of increased risk of coronary artery disease and obesity in N363S carriers in an Australian population (Lin et al., 2003a,b).

In conclusion, the N363S, BclI, and ER22/23EK polymorphisms in the GR gene, but not the TthIIII polymorphism, are associated with altered GC sensitivity and result in a wide variety of phenotypic signs. These are not pathological per se but may partially explain an individual's genetically determined tendency to a certain body composition and metabolic status (Figure 6). More research is needed to elucidate the mechanisms behind these associations at a molecular level.

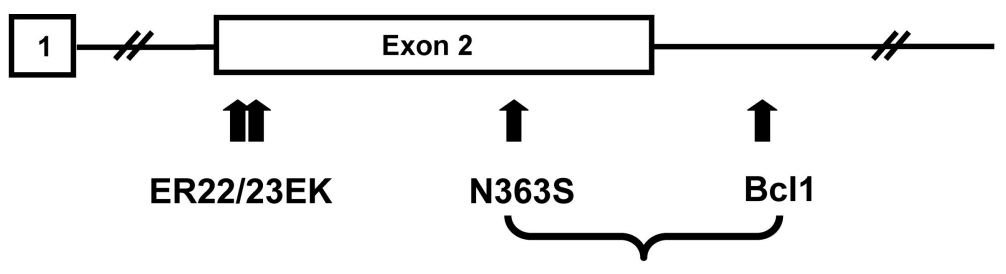

"Glucocorticoid Resistant"

Better body composition

Healthier metabolic profile

Better survival

Lower risk dementia
"Glucocorticoid Hypersensitive"

\author{
More body fat
}

Less lean mass

Hypersensitive insulin secretion Increased cholesterol levels

FIG. 6. A tentative scheme of the N-terminal part of the glucocorticoid receptor gene in which three functional polymorphisms are indicated as well as a summary of their clinical associations. 


\section{ACKNOWLEDGMENTS}

This research project was supported by a grant from the Dutch Organisation for Scientific Research (NWO) and a Research Institute of Diseases in the Elderly and NWO program grant entitled "Variations in Glucocorticoid Sensitivity."

\section{REFERENCES}

Bots ML, van Swieten JC, Breteler MM, de Jong PT, van Gijn J, Hofman A, Grobbee DE 1993 Cerebral white matter lesions and atherosclerosis in the Rotterdam Study. Lancet 341:12321237

Bray PJ, Cotton RG 2003 Variations of the human glucocorticoid receptor gene (NR3C1): pathological and in vitro mutations and polymorphisms. Hum Mutat 21:557-568

Breteler MM, van Amerongen NM, van Swieten JC, Claus JJ, Grobbee DE, van Gijn J, Hofman A, van Harskamp F 1994 Cognitive correlates of ventricular enlargement and cerebral white matter lesions on magnetic resonance imaging. The Rotterdam Study. Stroke 25:1109-1115

Brufsky AM, Malchoff DM, Javier EC, Reardon G, Rowe D, Malchoff CD 1990 A glucocorticoid receptor mutation in a subject with primary cortisol resistance. Trans Assoc Am Physicians 103:53-63

Buemann B, Vohl MC, Chagnon M, Chagnon YC, Gagnon J, Perusse L, Dionne F, Despres JP, Tremblay A, Nadeau A, Bouchard C 1997 Abdominal visceral fat is associated with a BclI restriction fragment length polymorphism at the glucocorticoid receptor gene locus. Obes Res 5:186-192

Cheek DB, Graystone JE, Seamark RF, McIntosh JE, Phillipou G, Court JM 1981 Urinary steroid metabolites and the overgrowth of lean and fat tissues in obese girls. Am J Clin Nutrit 34:1804-1810

Chrousos GP, Gold PW 1992 The concepts of stress and stress system disorders. Overview of physical and behavioral homeostasis. JAMA 267:1244-1252

Clement K, Philippi A, Jury C, Pividal R, Hager J, Demenais F, Basdevant A, Guy-Grand B, Froguel P 1996 Candidate gene approach of familial morbid obesity: linkage analysis of the glucocorticoid receptor gene. Intl J Obes Relat Metab Disord 20:507-512

De Kloet ER, Reul JM 1987 Feedback action and tonic influence of corticosteroids on brain function: a concept arising from the heterogeneity of brain receptor systems. Psychoneuroendocrinology 12:83-105

de Lange P, Koper JW, Huizenga NA, Brinkmann AO, de Jong FH, Karl M, Chrousos GP, Lamberts SW 1997 Differential hormone-dependent transcriptional activation and repression by naturally occurring human glucocorticoid receptor variants. Mol Endocrinol 11:11561164

Detera-Wadleigh S, Encio I, Rollins DY, Coffman D, Wiesch D 1991 A TthIIII polymorphism on the 5'-flanking region of the glucocorticoid receptor gene (GRL). Nucl Acids Res 19:1960

Di Blasio AM, van Rossum EFC, Maestrini S, Berselli ME, Tagliaferri M, Podesta F, Koper JW, Liuzzi A, Lamberts SWJ 2003 The relation between two polymorphisms in the glucocorticoid receptor gene and body mass index, blood pressure and cholesterol in obese patients. Clin Endocrinol 59:68-74

Diamond MI, Miner JN, Yoshinaga SK, Yamamoto KR 1990 Transcription factor interactions: selectors of positive or negative regulation from a single DNA element. Science 249:12661272

Dobson MG, Redfern CP, Unwin N, Weaver JU 2001 The N363S polymorphism of the glucocorticoid receptor: potential contribution to central obesity in men and lack of associ- 
ation with other risk factors for coronary heart disease and diabetes mellitus. J Clin Endocrinol Metab 86:2270-2274

Echwald SM, Sorensen TI, Andersen T, Pedersen O 2001 The Asn363Ser variant of the glucocorticoid receptor gene is not associated with obesity or weight gain in Danish men. Intl J Obes Relat Metab Disord 25:1563-1565

Fain JN, Ballou LR, Bahouth SW 2001 Obesity is induced in mice heterozygous for cyclooxygenase-2. Prostaglandins Oth Lipid Mediat 65:199-209

Feelders RA, van der Beld AW, Savelkoul HF, van Schaik RH, Bots ML, Stoerk S, Grobbee DE, Pols HA, Lamberts SW 2003 Endocrine and inflammatory determinants of atherosclerosis and mortality in elderly men. In: Program \& Abstracts of The Endocrine Society's 85th Annual Meeting. June 19-22, Philadelphia; abstract OR17-4, p 82

Feng J, Zheng J, Bennett WP, Heston LL, Jones IR, Craddock N, Sommer SS 2000 Five missense variants in the amino-terminal domain of the glucocorticoid receptor: no association with puerperal psychosis or schizophrenia. Am J Med Genet 96:412-417

Gottfries CG, Balldin J, Blennow K, Brane G, Karlsson I, Regland B, Wallin A 1994 Regulation of the hypothalamic-pituitary-adrenal axis in dementia disorders. Ann NY Acad Sci 746: 336-343; discussion 343-334

Guido EC, Delorme EO, Clemm DL, Stein RB, Rosen J, Miner JN 1996 Determinants of promoter-specific activity by glucocorticoid receptor. Mol Endocrinol 10:1178-1190

Halsall D, Luan J, Hales N, Wareham N, O'Rahilly S 2000 Glucocorticoid receptor variant and body mass index. Br Med J [http://bmj.com/cgi/eletters/319/7221/1337]

Haverkate F, Thompson SG, Pyke SD, Gallimore JR, Pepys MB 1997 Production of C-reactive protein and risk of coronary events in stable and unstable angina. European Concerted Action on Thrombosis and Disabilities Angina Pectoris Study Group. Lancet 349:462-466

Heck S, Kullmann M, Gast A, Ponta H, Rahmsdorf HJ, Herrlich P, Cato AC 1994 A distinct modulating domain in glucocorticoid receptor monomers in the repression of activity of the transcription factor AP-1. EMBO J 13:4087-4095

Huizenga NA, Koper JW, De Lange P, Pols HA, Stolk RP, Burger H, Grobbee DE, Brinkmann AO, De Jong FH, Lamberts SW 1998a A polymorphism in the glucocorticoid receptor gene may be associated with and increased sensitivity to glucocorticoids in vivo. J Clin Endocrinol Metab 83:144-151

Huizenga NA, Koper JW, de Lange P, Pols HA, Stolk RP, Grobbee DE, de Jong FH, Lamberts SW 1998b Interperson variability but intraperson stability of baseline plasma cortisol concentrations, and its relation to feedback sensitivity of the hypothalamo-pituitary-adrenal axis to a low dose of dexamethasone in elderly individuals. J Clin Endocrinol Metab 83:47-54

Hurley DM, Accili D, Stratakis CA, Karl M, Vamvakopoulos N, Rorer E, Constantine K, Taylor SI, Chrousos GP 1991 Point mutation causing a single amino acid substitution in the hormone binding domain of the glucocorticoid receptor in familial glucocorticoid resistance. J Clin Invest 87:680-686

Iida S, Nakamura Y, Fujii H, Nishimura J, Tsugawa M, Gomi M, Fukata J, Tarui S, Moriwaki K, Kitani T 1990 A patient with hypocortisolism and Cushing's syndrome-like manifestations: cortisol hyperreactive syndrome. J Clin Endocrinol Metab 70:729-737

Ikeda Y, Suehiro T, Shiinoki T, Kaneda T, Kumon Y, Hashimoto K 2001 A polymorphism in the promoter region of the glucocorticoid receptor gene is associated with its transcriptional activity. Endocr J 48:723-726

Jiang T, Liu S, Tan M, Huang F, Sun Y, Dong X, Guan W, Huang L, Zhou F 2001 The phase-shift mutation in the glucocorticoid receptor gene: potential etiologic significance of neuroendocrine mechanisms in lupus nephritis. Clin Chim Acta 313:113-117 
Karl M, Lamberts SW, Detera-Wadleigh SD, Encio IJ, Stratakis CA, Hurley DM, Accili D, Chrousos GP 1993 Familial glucocorticoid resistance caused by a splice site deletion in the human glucocorticoid receptor gene. J Clin Endocrinol Metab 76:683-689

Karl M, Lamberts SW, Koper JW, Katz DA, Huizenga NE, Kino T, Haddad BR, Hughes MR, Chrousos GP 1996a Cushing's disease preceded by generalized glucocorticoid resistance: clinical consequences of a novel, dominant-negative glucocorticoid receptor mutation. Proc Assoc Am Physicians 108:296-307.

Karl M, Von Wichert G, Kempter E, Katz DA, Reincke M, Monig H, Ali IU, Stratakis CA, Oldfield EH, Chrousos GP, Schulte HM 1996b Nelson's syndrome associated with a somatic frame shift mutation in the glucocorticoid receptor gene. J Clin Endocrinol Metab $81: 124-129$

Koper JW, Stolk RP, de Lange P, Huizenga NA, Molijn GJ, Pols HA, Grobbee DE, Karl M, de Jong FH, Brinkmann AO, Lamberts SW 1997 Lack of association between five polymorphisms in the human glucocorticoid receptor gene and glucocorticoid resistance. Hum Genet 99:663-668

Lamberts SW 2001 Hereditary glucocorticoid resistance. Ann Endocrinol (Paris) 62:164-167

Lamberts SW, Koper JW, Biemond P, den Holder FH, de Jong FH 1992 Cortisol receptor resistance: the variability of its clinical presentation and response to treatment. J Clin Endocrinol Metab 74:313-321

Lei SF, Deng FY, Liu XH, Huang QR, Qin Y, Zhou Q, Jiang DK, Li YM, Mo XY, Liu MY, Chen XD, Wu XS, Shen H, Dvornyk V, Zhao L, Recker RR, Deng HW 2003 Polymorphisms of four bone mineral density candidate genes in Chinese populations and comparison with other populations of different ethnicity. J Bone Miner Metab 21:34-42

Lin RC, Wang WY, Morris BJ 1999 High penetrance, overweight, and glucocorticoid receptor variant: case-control study. Br Med J 319:1337-1338

Lin RC, Wang XL, Dalziel B, Caterson ID, Morris BJ 2003a Association of obesity, but not diabetes or hypertension, with glucocorticoid receptor N363S variant. Obes Res 11:802-808

Lin RC, Wang XL, Morris BJ 2003b Association of coronary artery disease with glucocorticoid receptor N363S variant. Hypertension 41:404-407

Liuzzo G, Biasucci LM, Gallimore JR, Grillo RL, Rebuzzi AG, Pepys MB, Maseri A 1994 The prognostic value of $\mathrm{C}$-reactive protein and serum amyloid a protein in severe unstable angina. N Engl J Med 331:417-424

Lupien SJ, Gaudreau S, Tchiteya BM, Maheu F, Sharma S, Nair NP, Hauger RL, McEwen BS, Meaney MJ 1997 Stress-induced declarative memory impairment in healthy elderly subjects: relationship to cortisol reactivity. J Clin Endocrinol Metab 82:2070-2075

Malchoff DM, Brufsky A, Reardon G, McDermott P, Javier EC, Bergh CH, Rowe D, Malchoff CD 1993 A mutation of the glucocorticoid receptor in primary cortisol resistance. J Clin Invest 91:1918-1925

Marin P, Darin N, Amemiya T, Andersson B, Jern S, Bjorntorp P 1992 Cortisol secretion in relation to body fat distribution in obese premenopausal women. Metabolism 41:882-886

Mendonca BB, Leite MV, de Castro M, Kino T, Elias LL, Bachega TA, Arnhold IJ, Chrousos GP, Latronico AC 2002 Female pseudohermaphroditism caused by a novel homozygous missense mutation of the GR gene. J Clin Endocrinol Metab 87:1805-1809

Monder C, White PC 199311 beta-hydroxysteroid dehydrogenase. Vitam Horm 47:187-271

Murphy BE 1968 Clinical evaluation of urinary cortisol determinations by competitive proteinbinding radioassay. J Clin Endocrinol Metab 28:343-348

Murray JC, Smith RF, Ardinger HA, Weinberger C 1987 RFLP for the glucocorticoid receptor (GRL) located at 5q11-5q13. Nucl Acids Res 15:6765 
Nasman B, Olsson T, Viitanen M, Carlstrom K 1995 A subtle disturbance in the feedback regulation of the hypothalamic-pituitary-adrenal axis in the early phase of Alzheimer's disease. Psychoneuroendocrinology 20:211-220

Newfield RS, Kalaitzoglou G, Licholai T, Chilton D, Ashraf J, Thompson EB, New MI 2000 Normocortisolemic Cushing's syndrome initially presenting with increased glucocorticoid receptor numbers. J Clin Endocrinol Metab 85:14-21

Panarelli M, Holloway CD, Fraser R, Connell JM, Ingram MC, Anderson NH, Kenyon CJ 1998 Glucocorticoid receptor polymorphism, skin vasoconstriction, and other metabolic intermediate phenotypes in normal human subjects. J Clin Endocrinol Metab 83:1846-1852

Pasquali R, Cantobelli S, Casimirri F, Capelli M, Bortoluzzi L, Flamia R, Labate AM, Barbara L 1993 The hypothalamic-pituitary-adrenal axis in obese women with different patterns of body fat distribution. J Clin Endocrinol Metab 77:341-346

Pratt WB, Toft DO 1997 Steroid receptor interactions with heat shock protein and immunophilin chaperones. Endocr Rev 18:306-360

Reichardt HM, Kaestner KH, Tuckermann J, Kretz O, Wessely O, Bock R, Gass P, Schmid W, Herrlich P, Angel P, Schutz G 1998 DNA binding of the glucocorticoid receptor is not essential for survival. Cell 93:531-541

Rosmond R 2002 The glucocorticoid receptor gene and its association to metabolic syndrome. Obes Res 10:1078-1086

Rosmond R, Dallman MF, Bjorntorp P 1998 Stress-related cortisol secretion in men: relationships with abdominal obesity and endocrine, metabolic and hemodynamic abnormalities. J Clin Endocrinol Metab 83:1853-1859

Rosmond R, Chagnon YC, Chagnon M, Perusse L, Bouchard C, Bjorntorp P 2000a A polymorphism of the $5^{\prime}$-flanking region of the glucocorticoid receptor gene locus is associated with basal cortisol secretion in men. Metabolism 49:1197-1199

Rosmond R, Chagnon YC, Holm G, Chagnon M, Perusse L, Lindell K, Carlsson B, Bouchard C, Bjorntorp P 2000b A glucocorticoid receptor gene marker is associated with abdominal obesity, leptin, and dysregulation of the hypothalamic-pituitary-adrenal axis. Obes Res 8:211-218

Rosmond R, Bouchard C, Bjorntorp P 2001 Tsp509I polymorphism in exon 2 of the glucocorticoid receptor gene in relation to obesity and cortisol secretion: cohort study. Br Med J 322:652653

Ruiz M, Lind U, Gafvels M, Eggertsen G, Carlstedt-Duke J, Nilsson L, Holtmann M, Stierna P, Wikstrom AC, Werner S 2001 Characterization of two novel mutations in the glucocorticoid receptor gene in patients with primary cortisol resistance. Clin Endocrinol (Oxf) $55: 363-371$

Russcher H, Lamberts SWJ, van Rossum EFC, Brinkmann AO, de Jong FH, Koper JW 2003 Impaired translation of glucocorticoid receptor mRNA as a result of the ER22/23EK polymorphism. In: Program \& Abstracts of the $85^{\text {th }}$ Annual Meeting of The Endocrine Society. June 19-22, Philadelphia; abstract P2-31, p 315

Schaaf MJ, Cidlowski JA 2003 Molecular determinants of glucocorticoid receptor mobility in living cells: the importance of ligand affinity. Mol Cell Biol 23:1922-1934

Starkman MN, Gebarski SS, Berent S, Schteingart DE 1992 Hippocampal formation volume, memory dysfunction, and cortisol levels in patients with Cushing's syndrome. Biol Psychiat 32:756-765

Stenbit AE, Tsao TS, Li J, Burcelin R, Geenen DL, Factor SM, Houseknecht K, Katz EB, Charron MJ 1997 GLUT4 heterozygous knockout mice develop muscle insulin resistance and diabetes. Nature Med 3:1096-1101 
Stewart PM, Krozowski ZS 199911 beta-Hydroxysteroid dehydrogenase. Vitam Horm 57:249-324 Streeten DH, Stevenson CT, Dalakos TG, Nicholas JJ, Dennick LG, Fellerman H 1969 The diagnosis of hypercortisolism. Biochemical criteria differentiating patients from lean and obese normal subjects and from females on oral contraceptives. J Clin Endocrinol Metab 29:1191-1211

Thompson SG, Kienast J, Pyke SD, Haverkate F, van de Loo JC 1995 Hemostatic factors and the risk of myocardial infarction or sudden death in patients with angina pectoris. European Concerted Action on Thrombosis and Disabilities Angina Pectoris Study Group. N Engl J Med 332:635-641

Toft DO 1998 Recent advances in the study of hsp90 structure and mechanism of action. Trends Endocrinol Metab 9:238-243

Tremblay A, Bouchard L, Bouchard C, Despres JP, Drapeau V, Perusse L 2003 Long-term adiposity changes are related to a glucocorticoid receptor polymorphism in young females. J Clin Endocrinol Metab 88:3141-3145

Ukkola O, Perusse L, Chagnon YC, Despres JP, Bouchard C 2001a Interactions among the glucocorticoid receptor, lipoprotein lipase and adrenergic receptor genes and abdominal fat in the Quebec Family Study. Intl J Obes Relat Metab Disord 25:1332-1339

Ukkola O, Rosmond R, Tremblay A, Bouchard C 2001b Glucocorticoid receptor Bcl I variant is associated with an increased atherogenic profile in response to long-term overfeeding. Atherosclerosis 157:221-224

van Rossum EF, Koper JW, Huizenga NA, Uitterlinden AG, Janssen JA, Brinkmann AO, Grobbee DE, de Jong FH, van Duyn CM, Pols HA, Lamberts SW 2002 A polymorphism in the glucocorticoid receptor gene, which decreases sensitivity to glucocorticoids in vivo, is associated with low insulin and cholesterol levels. Diabetes 51:3128-3134

van Rossum EFC, de Jong FJ, den Heijer T, Koper JW, Koper JW, Uitterlinden AG, de Jong FH, Lamberts SWJ, Breteler MMB 2003a The Er22/23EK polymorphism in the glucocorticoid receptor gene protects against white matter lesions and dementia. In: Program \& Abstracts of the 85th Annual Meeting of The Endocrine Society. June 19-22, Philadelphia; abstract OR17-6, p 82

van Rossum EFC, Koper JW, Arp P, Uitterlinden AG, Janssen JAMJL, Brinkmann AO, Grobbee DE, de Jong FH, Pols HAP, Lamberts SWJ 2003b Identification of the Bcl I polymorphism in the glucocorticoid receptor gene: association with sensitivity to glucocorticoids in vivo, and body mass index. Clin Endocrinol 59:585-592

van Rossum EFC, Feelders RA, van den Beld AW, Uitterlinden AG, Janssen JAML, Ester W, Brinkmann AO, Grobbee DE, de Jong FH, Pols HAP, Koper JW, Lamberts SWJ 2004a The ER22/23EK polymorphism in the glucocorticoid receptor gene is associated with better survival and low C-reactive protein levels in elderly men. Am J Med, in press

van Rossum EFC, Voorhoeve PG, te Velde SJ, Koper JW, Delemarre-van de Waal HA, Kemper HCG, Lamberts SWJ 2004b The ER22/23EK polymorphism in the glucocorticoid receptor gene is associated with a beneficial body composition and muscle strength in young adults. $\mathrm{J}$ Clin Endocrinol Metab, in press

Vottero A, Kino T, Combe H, Lecomte P, Chrousos GP 2002 A novel, C-terminal dominant negative mutation of the GR causes familial glucocorticoid resistance through abnormal interactions with p160 steroid receptor coactivators. J Clin Endocrinol Metab 87:2658-2667

Watt GC, Harrap SB, Foy CJ, Holton DW, Edwards HV, Davidson HR, Connor JM, Lever AF, Fraser R 1992 Abnormalities of glucocorticoid metabolism and the renin-angiotensin system: a four-corners approach to the identification of genetic determinants of blood pressure. J Hypertens 10:473-482 
Weaver JU, Hitman GA, Kopelman PG 1992 An association between a Bc1I restriction fragment length polymorphism of the glucocorticoid receptor locus and hyperinsulinaemia in obese women. J Molec Endocrinol 9:295-300

Weiner J Lourie J 1968 Human Biology, a Guide to Field Methods. International Biological Programme Handbook no 9. Oxford, UK: Blackwell

Weverling-Rijnsburger AW, Blauw GJ, Lagaay AM, Knook DL, Meinders AE, Westendorp RG 1997 Total cholesterol and risk of mortality in the oldest old. Lancet 350:1119-1123

Yang-Yen HF, Chambard JC, Sun YL, Smeal T, Schmidt TJ, Drouin J, Karin M 1990 Transcriptional interference between c-Jun and the glucocorticoid receptor: mutual inhibition of DNA binding due to direct protein-protein interaction. Cell 62:1205-1215

Yudt MR, Cidlowski JA 2001 Molecular identification and characterization of a and b forms of the glucocorticoid receptor. Mol Endocrinol 15:1093-1103

Yudt MR, Cidlowski JA 2002 The glucocorticoid receptor: coding a diversity of proteins and responses through a single gene. Mol Endocrinol 16:1719-1726 